\title{
Prevalence and genetic characteristics of Salmonella in free-living birds in Poland
}

\author{
Marta Krawiec ${ }^{1}$, Maciej Kuczkowski ${ }^{1}$, Andrzej Grzegorz Kruszewicz ${ }^{2}$ and Alina Wieliczko ${ }^{1 *}$
}

\begin{abstract}
Background: Salmonella species are widespread in the environment, and occur in cattle, pigs, and birds, including poultry and free-living birds. In this study, we determined the occurrence of Salmonella in different wild bird species in Poland, focusing on five Salmonella serovars monitored in poultry by the European Union: Salmonella serovars Enteritidis, Typhimurium, Infantis, Virchow, and Hadar. We characterized their phenotypic and genetic variations. Isolates were classified into species and subspecies of the genus Salmonella with a polymerase chain reaction (PCR) assay. The prevalence of selected virulence genes (spvB, spiA, pagC, $c d t B, \operatorname{msgA}$, invA, sipB, prgA, spaN, orgA, tolC, iron $\mathrm{N}$, sitC, ipfC, sifA, $\operatorname{sop} \mathrm{B}$, and pefA) among the isolated strains was determined. We categorized all the Salmonella ser. Typhimurium strains with enterobacterial repetitive intergenic consensus (ERIC)-PCR.

Results: Sixty-four Salmonella isolates were collected from 235 cloacal swabs, 699 fecal samples, and 66 tissue samples (6.4\% of 1000 samples) taken from 40 different species of wild birds in Poland between September 2011 and August 2013. The largest numbers of isolates were collected from Eurasian siskin and greenfinch: 33.3\% positive samples for both. The collected strains belonged to one of three Salmonella subspecies: enterica (81.25\%), salamae (17.19\%), or houtenae (1.56\%). Eighteen strains belonged to Salmonella ser. Typhimurium (28.13\%), one to ser. Infantis (1.56\%), one to ser. Virchow (1.56\%), and one to ser. Hadar (1.56\%). All isolates contained spiA, msgA, invA, IpfC, and sifA genes; $94.45 \%$ of isolates also contained sitC and sopB genes. None of the Salmonella ser.

Typhimurium strains contained the $c d t B$ gene. The one Salmonella ser. Hadar strain contained all the tested genes, except spvB and pefA; the one Salmonella ser. Infantis strain contained all the tested genes, except tspvB, pefA, and $c d t B$; and the one Salmonella ser. Virchow strain contained all the tested genes, except spvB, pefA, $c d t B$, and tolC. The Salmonella ser. Typhimurium strains varied across the same host species, but similarity was observed among strains isolated from the same environment (e.g., the same bird feeder or the same lake).
\end{abstract}

Conclusions: Our results confirm that some wild avian species are reservoirs for Salmonella serotypes, especially Salmonella ser. Typhimurium.

Keywords: Free-living birds, Salmonella spp, Poland, Virulence genes, ERIC-PCR

\section{Background}

Salmonella species are widespread in nature, and occur as pathogenic bacteria in the intestines of domestic and wild animals, including birds. Cases of suspected birdto-human transmission of Salmonella have been reported [1]. Most identified Salmonella serovars have been Salmonella enterica and almost all are able to cause illness in humans and animals [2]. The most

\footnotetext{
*Correspondence: alina.wieliczko@up.wroc.pl

'Department of Epizootiology and Clinic of Bird and Exotic Animals, Faculty of Veterinary Medicine, Wrocław University of Environmental and Life

Sciences, PI. Grunwaldzki 45, 50-366 Wrocław, Poland

Full list of author information is available at the end of the article
}

frequently reported serotypes causing human salmonellosis in the European Union (EU) are S. enterica subsp. enterica serovar (ser.) Enteritidis and S. enterica subsp. enterica ser. Typhimurium [3]. Because of the suspected high correlation between salmonellosis in poultry and the number of human infections, Directive 2003/99/EC of the European Parliament and Council requires that the following five serotypes of Salmonella be monitored in poultry flocks: Enteritidis, Typhimurium, Virchow, Hadar, and Infantis. Some strains of Salmonella ser. Typhimurium have been identified as host adapted and a cause of salmonellosis in pigeons [4] and passerines [5]. Infections with different serotypes of Salmonella 
have also been documented in gulls, crows, vultures, and parrots [6,7]. Salmonella is an environmentally persistent pathogen that can survive and proliferate in diverse environments, including in animals that form part of the human food chain [8]. The molecular characterization of Salmonella serovars isolated from poultry, food, and the environment has been reported (e.g., virulence genes and the homology of strains) [9-12]. In contrast, there are few reports of the characterization of strains isolated from wild birds throughout the world. The aim of this study was to isolate and characterize Salmonella strains from selected free-living bird species in Poland.

\section{Methods}

During the period from September 2011 to August 2013, 1000 samples were collected: 235 cloacal swabs from four species of aquatic wild birds, and 699 fecal samples and 66 tissue samples from 36 different species of freeliving birds (Table 1). Birds found dead and feces were collected by ornithologists from live and dead individuals in six different regions of Poland during the following bird-ringing seasons:

- winter and early spring in the Wrocław city center, suburbs, and parks, the ponds in the Lower Silesia region, the Baltic coast, and two wildlife rescue centers;

- summer and early autumn in the Rakutowskie Lake of Kuyavian-Pomeranian Voivodeship (northern Poland) and in the Sudetic Mountains (southern Poland).

The ornithologists ringed the birds with the consent of the General Directorate of Environmental Protection, Poland (nos. 253/2012 and 259/2013).

Cloacal swabs from mallard ducks and black coots were obtained during the hunting season by two hunting associations in accordance with local hunting laws, special permission (with the consent of the Regional Directorate of Environmental Protection, Wrocław, Poland, no. WPN. 6205.67.2012.MK.1), and hunting programs. Samples from great cormorants were obtained during the annual population cull in Poland. All cloacal swabs from mallards, black coots, and great cormorants were collected in the lakes of the Lower Silesia region between August 15, 2012, and December 12, 2012. Cloacal swabs were collected from velvet scoters that were found dead in fishing nets on the Baltic coast in late winter and early spring.

The species of birds were grouped by their preferred habitats and/or behavior and were divided into waterfowl, songbirds, and birds kept in rescue centers, as well as migratory, partially migratory, or resident species (Table 1). The research was conducted with the consent of the $2^{\text {nd }}$ Local Ethical Committee for Animal Experiments (Wrocław, Poland; no. 41/2011).

\section{Bacterial isolation}

All the samples were analyzed for Salmonella strains, which were isolated using the International Organization for Standardization Procedure PN-EN ISO 6579: 2003/A1: 2007. The samples were pre-enriched in nonselective buffered peptone water (Merck, Darmstadt, Germany) for 20 $\mathrm{h}$ at $37^{\circ} \mathrm{C}$. After incubation, enriched modified semisolid Rappaport-Vassiliadis medium (Merck) was inoculated with the samples and incubated for $24 \mathrm{~h}$ at $41.5^{\circ} \mathrm{C}$. The cultures were differentiated on solid xylose-lysine-deoxycholate agar (Merck) and on MacConkey agar (Merck), incubated for $24 \mathrm{~h}$ at $37^{\circ} \mathrm{C}$. Three colonies per plate with the characteristics of Salmonella spp. were then spread onto nutrient agar (Merck) and incubated for $24 \mathrm{~h}$ at $37^{\circ}$ $\mathrm{C}$. The colonies were then identified biochemically with the API 20E system (Biomerieux, Marcy l'Etoile, France). All isolates were stored in Microbank vials (Microbank, Pro-Lab Diagnostics, Round Rock, TX, USA) at $-70^{\circ} \mathrm{C}$ for further analysis.

\section{DNA extraction}

After the cells were incubated overnight at $37^{\circ} \mathrm{C}$ on nutrient agar (Merck), the bacterial genomic DNA was extracted using the DNeasy ${ }^{\circ}$ Blood \& Tissue Kit (Qiagen, Valencia, CA, USA), according to the manufacturer's instructions. The DNA was quantified spectrophotometrically (BioPhotometer, Eppendorf, Wesseling-Berzdorf, Germany) and stored at $-20^{\circ} \mathrm{C}$.

\section{Salmonella identification with PCR}

The genus Salmonella was confirmed with multiplex PCR. Salmonella was identified at the genus level with the $\operatorname{inv} A$ gene and at the subspecies level with the same multiplex PCR. The primer sequences used for amplification are summarized in Table 2. Salmonella was identified at the genus and subspecies levels according to Lee et al. [13].

\section{Salmonella serotyping}

Salmonella isolates were serotyped using single-factor antisera (Sifin, Berlin, Germany), according to the White-Kauffman-Le Minor scheme, focusing particularly on the five serovars mentioned above, which are monitored in poultry by the EU.

Enterobacterial repetitive intergenic consensus (ERIC)-PCR The genetic diversity of the isolated Salmonella ser. Typhimurium strains was analyzed with ERIC-PCR, using a protocol and primers (ERIC-R: 5'-ATGTAAG CTCCTGGGGATTCAC-3'; ERIC-F: 5'-AAGTAAGT GACTGGGGTGAGCG-3') targeting the palindromic 
Table 1 Salmonella isolates obtained from free-living birds

\begin{tabular}{|c|c|c|c|c|c|}
\hline No. & Origin & $\begin{array}{l}\text { Type of } \\
\text { material }\end{array}$ & $\begin{array}{l}\text { Total amount of tested } \\
\text { individuals }\end{array}$ & $\begin{array}{l}\text { Positive samples } \\
\text { (\%) }\end{array}$ & Environmental data $* / * *$ \\
\hline 1 & Mallard duck Anas platyrhynchos & cloacal swabs & $121(d)$ & $8(6,61)$ & $1 / \mathrm{A}$ \\
\hline 2 & Great cormorant Phalacrocorax carbo & cloacal swab & $77(d)$ & $8(10,39)$ & $1 / \mathrm{A}$ \\
\hline 3 & Velvet scoter Melanitta fusca & cloacal swab & $30(d)$ & $0(0,00)$ & $7 / \mathrm{A}$ \\
\hline 4 & Black coot Fulica atra & cloacal swab & 7 (d) & $0(0,00)$ & $1 / \mathrm{B}$ \\
\hline 5 & Mute swan Cygnus olor & feces & 27 (a) & $0(0,00)$ & $1,2 / \mathrm{A}$ \\
\hline 6 & Whooper swan Cygnus cygnus & feces & 6 (a) & $0(0,00)$ & $1,2 / \mathrm{A}$ \\
\hline 7 & Great tit Parus major & feces/tissue & $109(92 \mathrm{a} / 17 \mathrm{~d})$ & $10(9,17)$ & $3,4,5,6 / \mathrm{B}$ \\
\hline 8 & Blue tit Cyanistes caeruleus & feces/tissue & $43(36 a / 7 d)$ & $1(2,32)$ & $3,4,5,6 / C$ \\
\hline 9 & Eurasian tree sparrow Passer montanus & feces/tissue & $53(48 a / 5 d)$ & $2(3,77)$ & $3,4,5,6 / C$ \\
\hline 10 & Redpoll Carduelis cabaret & feces & 57 (a) & $1(1,75)$ & $6 / \mathrm{A}$ \\
\hline 11 & Eurasian siskin Carduelis spinus & feces/tissue & $48(39 a / 9 d)$ & $16(33,3)$ & $3,4,5,6 / \mathrm{A}$ \\
\hline 12 & Common chiffchaff Phylloscopus collybita & feces & $45(a)$ & $0(0,00)$ & $5,6 / \mathrm{A}$ \\
\hline 13 & Bluethroat Luscinia svecica & feces & 43 (a) & $0(0,00)$ & $3,4,5,6 / \mathrm{A}$ \\
\hline 14 & European robin Erithacus rubecula & feces & $36(a)$ & $0(0,00)$ & $5,6 / \mathrm{A}$ \\
\hline 15 & $\begin{array}{l}\text { Common reed bunting Emberiza } \\
\text { schoeniclus }\end{array}$ & feces & 35 (a) & $0(0,00)$ & $3,4,5,6 /$ \\
\hline 16 & Eurasian blackcap Sylvia atricapilla & feces & $35(a)$ & $0(0,00)$ & $3,4,5,6 / \mathrm{B}$ \\
\hline 17 & Greenfinch Carduelis chloris & feces/tissue & $30(20 a / 10 d)$ & $10(33,3)$ & $\begin{array}{l}3,4,5,6 / C \text { some } \\
\text { populations } \mathrm{A}\end{array}$ \\
\hline 18 & Pied flycatcher Ficedula hypoleuca & feces & 19 (a) & $0(0,00)$ & $6 / A$ \\
\hline 19 & Hedge sparrow Prunella modularis & feces & 17 (a) & $0(0,00)$ & $5,6 / \mathrm{B}$ \\
\hline 20 & Barn swallow Hirundo rustica & feces & 17 (a) & $0(0,00)$ & $3,4,5,6 / \mathrm{A}$ \\
\hline 21 & Common starling Sturnus vulgaris & feces/tissue & $16(13 a / 3 d)$ & $3(18,75)$ & $3,4,5,6$ \\
\hline 22 & $\begin{array}{l}\text { Eurasian reed warbler Acrocephalus } \\
\text { scirpaceus }\end{array}$ & feces & $15(a)$ & $0(0,0)$ & $5,6 / \mathrm{A}$ \\
\hline 23 & Fieldfare Turdus pilaris & feces & 13(a) & $0(0,0)$ & $5,6 / \mathrm{A}$ \\
\hline 24 & Yellow wagtail Motacilla flava & feces & $13(a)$ & $0(0,0)$ & $3,4,5,6 / \mathrm{A}$ \\
\hline 25 & Blackbird Turdus melura & feces/tissue & $11(10 \mathrm{a} / 1 \mathrm{~d})$ & $1(9,09)$ & $3,4,5,6 / B$ \\
\hline 26 & Common chaffinch Fringilla coelebs & feces & $9(a)$ & $0(0,00)$ & $3,4,5,6 / \mathrm{B}$ \\
\hline 27 & Whitethroat Sylvia borin & feces & 9 (a) & $0(0,00)$ & $5,6 / \mathrm{A}$ \\
\hline 28 & Yellow- hammer Emberiza citrinella & feces & 7 (a) & $0(0,00)$ & $3,4,5,6 / B$ \\
\hline 29 & Lesser whitethroat Sylvia curruca & feces & 7 (a) & $0(0,00)$ & $5,6 / \mathrm{A}$ \\
\hline 30 & Long-tailed tits Aegithalos caudatus & feces & $6(\mathrm{a})$ & $0(0,00)$ & $6 / B$ \\
\hline 31 & Hooded crow Corvus cornix & tissue & $6(d)$ & $0(0,00)$ & $2 / B$ \\
\hline 32 & Rook Corvus frugilegus & feces/tissue & $6(3 a / 3 d)$ & $1(16,66)$ & $2 / \mathrm{A}$ \\
\hline 33 & $\begin{array}{l}\text { Common wood pigeon Columba } \\
\text { palumbus }\end{array}$ & feces/tissue & $6(2 a / 4 d)$ & $1(16,67)$ & $2 / \mathrm{A}$ \\
\hline 34 & Common swift Apus apus & feces/tissue & $5(4 a / 1 d)$ & $1(20,00)$ & $3,4,5,6 / \mathrm{A}$ \\
\hline 35 & Willow worbler Phylloscopus trochilus & feces & $5(a)$ & $0(0,00)$ & $6 / A$ \\
\hline 36 & Willow tit Poecile montanus & feces & 5 (a) & $0(0,00)$ & $3,4,5,6 / \mathrm{B}$ \\
\hline 37 & Eurasian marsh harrier Circus aeruginosus & feces & $1(\mathrm{a})$ & $1(100,00)$ & $8 / \mathrm{A}$ \\
\hline
\end{tabular}


Table 1 Salmonella isolates obtained from free-living birds (Continued)

\begin{tabular}{lllll}
\hline 38 & Sparrowhawk Accipiter nisus & feces & $1(\mathrm{a})$ & $0(0,00)$ \\
39 & Common buzzard Buteo buteo & feces & $1(\mathrm{a})$ & $0(0,00)$ \\
40 & Golden eagle Aquila chrysaetos & feces & $3(\mathrm{a})$ & $0(0,00)$ \\
\hline
\end{tabular}

$\mathrm{d}$, dead individuals; a, alive individuals;

The boldfaces indicate the species of birds with the highest amount (percent) of positive samples.

*Locations of sample collection:

1. Lakes of the Lower Silesia region (southern Poland).

2. Parks of Wrocław (southern Poland).

3. Bird feeders in Wrocław city center (southern Poland).

4. Bird feeders in the suburbs of Wrocław (southern Poland).

5. Rakutowskie Lake of Kuyavian-Pomeranian Voivodeship (middle Poland).

6. Sudetic Mountains (southern Poland).

7. Baltic coast (northern Poland).

8. Wildlife rescue center in Lower Silesia (southern Poland).

9. Wildlife rescue center in Greater Poland (middle Poland).

** Lifestyles of birds: A, migratory bird; B, partially migratory bird; C, resident.

sequences of ERIC with the method described by Versalovic et al. [14].

\section{PCR detection of virulence genes}

The virulence genotyping of Salmonella ser. Typhimurium (18 strains), Salmonella ser. Hadar (one strain), Salmonella ser. Virchow (one strain), and Salmonella ser. Infantis (one strain) was performed with the multiplex PCR described by Skyberg et al. [9]. The primers used in this experiment are listed in Table 3.

\section{Positive controls}

Two strains, Salmonella ser. Typhimurium (ATCC \# 14028) and Salmonella ser. Hadar (laboratory strain), previously shown to contain all the genes tested (Salmonella species, subspecies and virulence genes), served as positive control strains. Identity of Salmonella ser. Hadar strain was verified by sequencing.

\section{Results}

\section{Isolation and identification}

Salmonella species were isolated from $64(6.4 \%)$ of the 1000 samples collected (Tables 1 and 4). Most of the positive samples came from the Eurasian siskin (Carduelis spinus) $(16 / 48,33.33 \%)$ and the greenfinch (Carduelis chloris; 10/30, 33.33\%). Positive samples were also collected from 13 other species, including the great cormorant (Phalacrocorax carbo; 8/77, 10.39\%), great tit (Parus major; 10/109, 9.17\%), and mallard duck (Anas platyrhynchos; 8/121, 6.61\%). A positive sample was also obtained from a Eurasian marsh harrier (Circus aeruginosus; 1/1, 100.00\%). This last sample was collected from the bird during its second day at a wildlife rescue center in Lower Silesia before antibiotic treatment was commenced (Table 1).

The collected Salmonella strains all belonged to one of three subspecies: enterica (81.25\%), salamae (17.19\%), or houtenae (1.56\%). S. enterica subsp. enterica was isolated from the vast majority of bird species, but S. enterica subsp. salamae was collected from four species of birds (Eurasian tree sparrow, great cormorant, great tit, and common swift). Only one strain, isolated from a mallard duck, was S. enterica subsp. houtenae (Table 4).

Among the Salmonella strains collected, four of the five serovars of Salmonella that are constantly monitored by the EU in poultry were found in free-living birds. Eighteen strains belonged to ser. Typhimurium (28.13\%), one to ser. Infantis (1.56\%), one to ser. Virchow (1.56\%), and one to ser. Hadar (1.56\%). No Salmonella ser. Enteritidis was isolated from any sample collected from free-living birds. Serovars Virchow and Infantis were isolated from two very young starlings. Serovar Hadar was isolated from the mallard duck. Serovar Typhimurium was the serovar isolated from the greatest number of bird species (Table 4).

ERIC-PCR categorized the 18 Salmonella ser. Typhimurium strains obtained from free-living birds into different profiles. One strain remained as nonhomologous to any other strain. The Salmonella ser. Typhimurium strains showed no correlation with bird species (e.g., isolates from Eurasian siskin nos. 22, 42, and 16 differed), but similarity was observed among the strains isolated from the same environmental areas (strain nos. 60, 12, 2, 18 , and 37 were similar). The first cluster included strains collected in two regions: Wrocław city center and suburbs. The Salmonella ser. Typhimurium isolates collected from dead birds also displayed genetic diversity (Figure 1).

All the isolated Salmonella ser. Typhimurium strains contained the spiA, msgA, invA, lpfC, and sif A genes; $94.45 \%$ isolates also contained the sitC and $\operatorname{sop} \mathrm{B}$ genes. None of the Salmonella ser. Typhimurium strains contained the $c d t B$ gene. The presence of other genes was investigated. The genes in the Salmonella ser. Typhimurium strains were highly variable. The one Salmonella ser. Hadar strain contained all the tested genes, except $s p v \mathrm{~B}$ and $p e f \mathrm{~A}$; the one Salmonella ser. Infantis strain contained all the tested genes, except $s p v \mathrm{~B}, p e f \mathrm{~A}$, and $c d t B$; and the one Salmonella ser. Virchow contained all the tested genes, except $s p v \mathrm{~B}, p e f \mathrm{~A}, c d t B$, and 
Table 2 Primers used in PCR to identify species and subspecies of Salmonella strains, according to Lee et al. [13]

\section{Genes}

STM

\section{Function of gene}

encodes a putative inner membrane protein, specific for S. enterica subsp I

encodes Salmonella enterotoxin and is specific for S. enterica

invasion protein, for simultaneous identification of Salmonella at the genus level

encodes the galacitol-1-phosphate dehydrogenase (gatD), contributes to acid production from galacitol

encodes the alpha subunit of the enzyme that contributes to malonate utilization

encodes phase 2 flagellin, enables differentiation between monophasic and diphasic subspecies

\section{Sequence of nucleotides}

F-GGTGGCCTCGATGATTCCCG

Size

R-CCCACTTGTAGCGAGCGCCG

F-CGATCCCTITCCCGCTATC

R-GGCGAATGAGACGCTTAAG

F-ACAGTGCTCGTTTACGACCTGAAT

R-AGACGACTGGTACTGATCGATAAT

F-GGCGCCATTATTATCCTATTAC

R-CATTTCCCGGCTATTACAGGTAT

F-GGATGTACTCTTCCATCCCCAGT

R-CGTAGCGAGCATCTGGATATCTIT

F-GACTCCATCCAGGCTGAAATCAC

R-CGGCTTTGCTGGCATTGTAG 
Table 3 Primers used in PCR to detect the virulence genes in Salmonella strains, according to Skyberg et al. [9]

\begin{tabular}{|c|c|c|c|}
\hline Genes & Function of gene & Sequence of nucleotides & Size \\
\hline \multirow[t]{2}{*}{$s p \vee B$} & Growth within host & F-CTATCAGCCCCGCACGGAGAGCAGTIITA & $717 \mathrm{bp}$ \\
\hline & & R-GGAGGAGGCGGTGGCGGTGGCATCATA & \\
\hline \multirow[t]{2}{*}{ spiA } & Survival within macrophage & F-CCAGGGGTCGTTAGTGTATTGCGTGAGATG & $550 \mathrm{bp}$ \\
\hline & & R-CGCGTAACAAAGAACCCGTAGTGATGGATT & \\
\hline \multirow[t]{2}{*}{ pagC } & Survival within macrophage & F-CGCCTITTCCGTGGGGTATGC & $454 \mathrm{bp}$ \\
\hline & & R-GAAGCCGTTTATTITTGTAGAGGAGATGTT & \\
\hline \multirow[t]{2}{*}{$c d t B$} & Host recognition/invasion & F-ACAACTGTCGCATCTCGCCCCGTCATT & $268 \mathrm{bp}$ \\
\hline & & R-CAATTTGCGTGGGTTCTGTAGGTGCGAGT & \\
\hline \multirow[t]{2}{*}{$m s g A$} & Survival within macrophage & F-GCCAGGCGCACGCGAAATCATCC & $189 \mathrm{bp}$ \\
\hline & & R-GCGACCAGCCACATATCAGCCTCTTCAAAC & \\
\hline \multirow[t]{2}{*}{ inva } & Host recognition/invasion & F-CTGGCGGTGGGTTTTGTTGTCTTCTCTATT & $1070 \mathrm{bp}$ \\
\hline & & R-AGTTTCTCCCCCTCTTCATGCGTTACCC & \\
\hline \multirow[t]{2}{*}{$\operatorname{sip} B$} & Entry into nonphagocytic cells & F-GGACGCCGCCCGGGAAAAACTCTC & $875 \mathrm{bp}$ \\
\hline & & R-ACACTCCCGTCGCCGCCTTCACAA & \\
\hline \multirow[t]{2}{*}{$\mathrm{prgH}$} & Host recognition/invasion & F-GCCCGAGCAGCCTGAGAAGTTAGAAA & $756 \mathrm{bp}$ \\
\hline & & R-TGAAATGAGCGCCCCTTGAGCCAGTC & \\
\hline \multirow[t]{2}{*}{ span } & Entry into nonphagocytic cells & F-AAAAGCCGTGGAATCCGTTAGTGAAGT & $504 \mathrm{bp}$ \\
\hline & & R-CAGCGCTGGGGATTACCGTTTTG & \\
\hline \multirow[t]{2}{*}{$\operatorname{org} A$} & Host recognition/invasion & F-TTITGGCAATGCATCAGGGAACA & $255 \mathrm{bp}$ \\
\hline & & R-GGCGAAAGCGGGGACGGTATT & \\
\hline \multirow[t]{2}{*}{ tolc } & Host recognition/invasion & F-TACCCAGGCGCAAAAAGAGGCTATC & $161 \mathrm{bp}$ \\
\hline & & R-CCGCGTTATCCAGGTTGTTGC & \\
\hline \multirow[t]{2}{*}{ iron } & Iron acquisition & F-ACTGGCACGGCTCGCTGTCGCTCTAT & $1205 \mathrm{bp}$ \\
\hline & & R-CGCTITACCGCCGTTCTGCCACTGC & \\
\hline \multirow[t]{2}{*}{ sitC } & Iron acquisition & F-CAGTATATGCTCAACGCGATGTGGGTCTCC & $768 \mathrm{bp}$ \\
\hline & & R-CGGGGCGAAAATAAAGGCTGTGATGAAC & \\
\hline \multirow[t]{2}{*}{ IpfC } & Host recognition/invasion & F-GCCCCGCCTGAAGCCTGTGTTGC & $641 \mathrm{bp}$ \\
\hline & & R-AGGTCGCCGCTGTITGAGGTTGGATA & \\
\hline \multirow[t]{2}{*}{ sifA } & Filamentous structure formation & F-TTTGCCGAACGCGCCCCCACACG & $449 \mathrm{bp}$ \\
\hline & & R-GTTGCCTITTCTTGCGCTTTCCACCCATCT & \\
\hline \multirow[t]{2}{*}{$\operatorname{sop} B$} & Host recognition/invasion & F-CGGACCGGCCAGCAACAAAACAAGAAGAAG & $220 \mathrm{bp}$ \\
\hline & & R-TAGTGATGCCCGTTATGCGTGAGTGTATT & \\
\hline \multirow[t]{2}{*}{ pefA } & Host recognition/invasion & F-GCGCCGCTCAGCCGAACCAG & $157 \mathrm{bp}$ \\
\hline & & R-GCAGCAGAAGCCCAGGAAACAGTG & \\
\hline
\end{tabular}

tolC. The prevalence of virulence genes in the Salmonella ser. Typhimurium strains varied among the live and dead free-living birds (Figure 1).

\section{Discussion}

The results of this study confirm that Salmonella ser. Typhimurium, one of the most frequently reported serotypes in human salmonellosis in the EU, occurs among free-living birds. Three other serotypes monitored in poultry flocks by the EU, Hadar, Virchow, and Infantis, were also present among the free-living bird populations.
Free-living birds are considered to be potential carriers of these bacteria and to play a role in the ecology and circulation of several zoonotic pathogens [4-7].

In Central Europe, only a few reports of salmonellosis in wild birds have been published, in the 1990s [7,15]. In Poland, all similar research has been conducted in the small northern region of the country, and there is a dearth of wide epidemiological studies in this field [16,17].

Salmonella infection may occur as a visible illness or be asymptomatic, depending upon the bird species. It 
Table 4 Species, subspecies, and serotypes of Salmonella isolates collected

\begin{tabular}{|c|c|c|c|c|}
\hline Species & Subspecies & Serotype & Origin & Number of isolates \\
\hline \multirow[t]{25}{*}{ Salmonella enterica } & enterica (I) & Typhimurium 4,12::1:1,2 & Eurasian siskin & 7 \\
\hline & & & Greenfinch & 3 \\
\hline & & & Mallard duck & 3 \\
\hline & & & Redpoll & 1 \\
\hline & & & Common wood pigeon & 1 \\
\hline & & & Blue tit & 1 \\
\hline & & & Great tit & 1 \\
\hline & & & Blackbird & 1 \\
\hline & & Infantis 6,7:r:1,5 & Common starling & 1 \\
\hline & & Virchow 6,7:r:1,2 & Common starling & 1 \\
\hline & & Hadar $6,8: z_{10}: e, n, x$ & Mallard duck & 1 \\
\hline & & others & Eurasian siskin & 8 \\
\hline & & & Great cormorant & 7 \\
\hline & & & Mallard duck & 4 \\
\hline & & & Common starling & 1 \\
\hline & & & Greenfinch & 7 \\
\hline & & & Great tit & 1 \\
\hline & & & Rook & 1 \\
\hline & & & Eurasian marsh harrier & 1 \\
\hline & & & Eurasian tree sparrow & 1 \\
\hline & salamae (II) & others & Eurasian tree sparrow & 1 \\
\hline & & & Great cormorant & 1 \\
\hline & & & Great tit & 8 \\
\hline & & & Common swift & 1 \\
\hline & houtenae (IV) & others & Mallard duck & 1 \\
\hline
\end{tabular}

may also result from exposure to an environment that has been contaminated by infected humans or livestock $[15,18,19]$. Migratory birds, in particular, are potential reservoirs for bacterial agents [20]. Many wild passerines have been documented as carriers of Salmonella strains, and their involvement in the transmission of Salmonella to mammals and people has been suggested [21,22]. In this study, most of the positive samples came from garden bird species: Eurasian siskins and greenfinches. These results are compatible with the findings of Hughes et al. [23], who reported that Salmonella caused mortality in wild birds, particularly garden birds, in the United Kingdom. Lawson et al. [24] also reported that house sparrows and greenfinches are particularly susceptible to salmonellosis. Consistent with our results, it has also been documented that the Salmonella serovar most commonly isolated from free-living birds is ser. Typhimurium, which appears to be adapted to some avian species that frequent bird feeders, including songbirds [25]. The results of the present study clearly show that the bird species with the highest proportion of
Salmonella-positive samples also frequented bird feeders. Both European siskins and greenfinches seem to be particularly susceptible to Salmonella ser. Typhimurium. This result suggests a high incidence of Salmonella exposure near bird feeders during winter and its transmission to birds. It can be inferred that the risk of transmission from the feces of infected wild passerines to uninfected birds is high, especially in urban areas with many bird feeders. As reported by Hamer et al. [25] and later noted by Borreli et al. [26], the key features of the urban environment that promote the transmission of pathogens include increased host contact rates, susceptibility to infection, high rates of pathogen introduction, pollution and stress (which reduce the host immune function), and warmer microclimates with reduced seasonality (which allow the environmental persistence of some pathogens). These factors may explain the increased frequency of salmonellosis we observed in birds between February and April during a prolonged winter in Poland in 2013 (data not shown in the table). In the United Kingdom, Hughes et al. [23] reported similar 


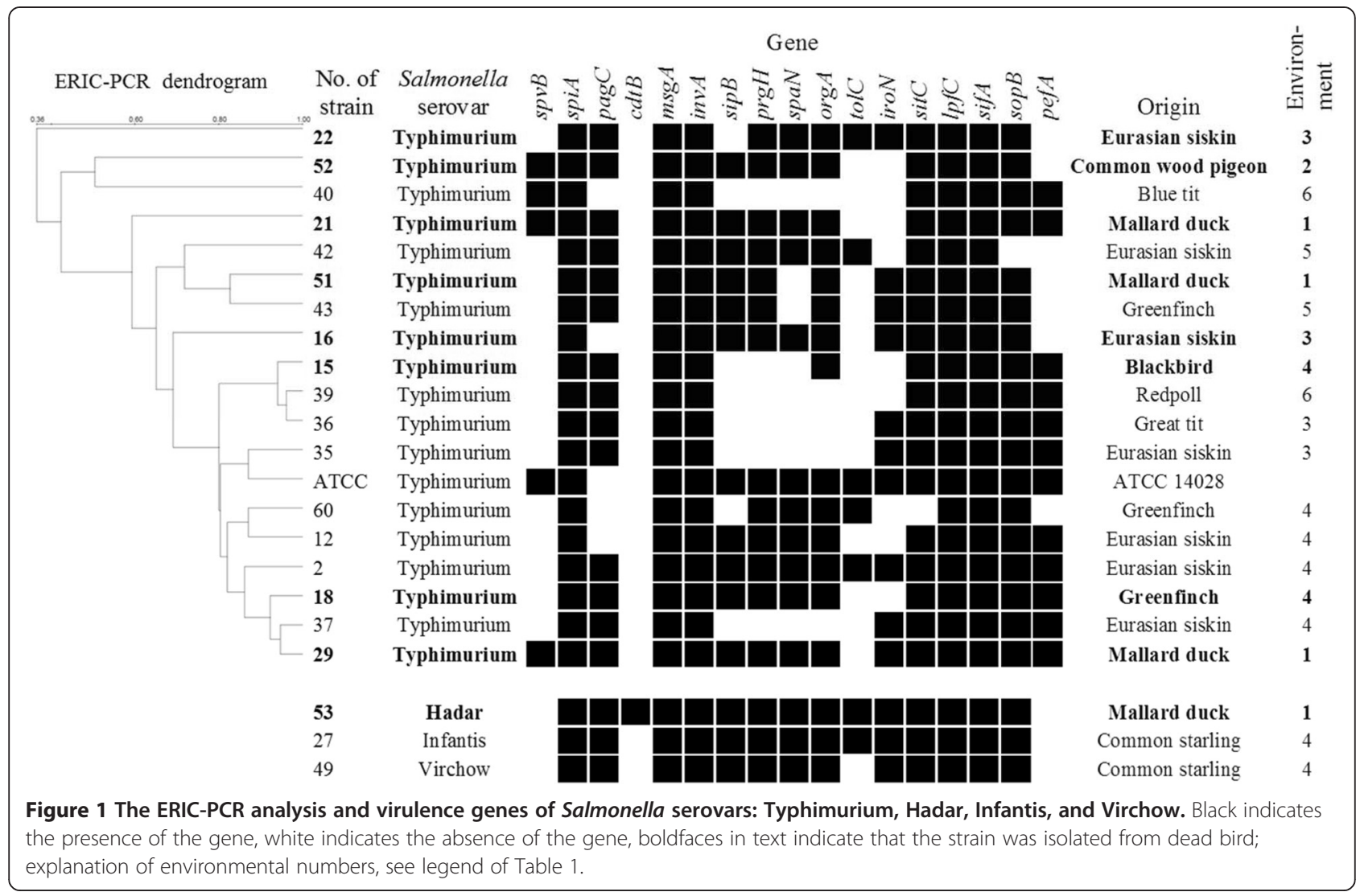

peaks of Salmonella isolation in January and February. Kapperud et al. [18] documented the seasonality of salmonellosis outbreaks, simultaneously in people and wild passerines, in Norway in 1998, which appeared in both groups between January and April. It is also possible that salmonellosis outbreaks in free-living birds during this time of year are associated with the feeding of birds by people. Supplemental feeding creates high densities of birds, high concentrations of feces, and stress arising from social interactions, which may also increase the prevalence of some bacterial species among wild birds [25]. It has been suggested that certain strains of Salmonella ser. Typhimurium are associated with different groups of wild birds [19,23,27-30]. This is supported by the recovery of this serotype from mallard ducks and great cormorants in this study.

Daoust and Prescott [31] reported that salmonellosis can cause sporadic mortality, particularly among birds around feeders, but also in young birds in large breeding colonies. These results prompted us to check the prevalence of selected virulence genes (encoding virulence factors) that are also capable of causing human infections $[9,10,12]$. In this study, we have demonstrated the great variability in the virulence genes present in isolated Salmonella strains in both dead and live birds, and among birds of the same species.
Similar results for the prevalence of virulence genes have been reported by other researchers. Skyberg et al. [9] recorded that the same 17 virulence genes were widespread in many Salmonella serovars isolated from both sick and healthy birds. Similar findings were recorded by Mezal et al. [11] among environmental samples, including dust, water, and other materials from poultry houses. Our study confirms the presence of the same virulence genes, which might play important roles in the bacterial invasion and survival in the host of Salmonella isolates collected from different species of freeliving birds, as in human clinical isolates. These findings suggest that like poultry flocks, poultry houses, and the environments around poultry farms, wild birds might be a source of Salmonella strains that are pathogenic to people. We also found evidence that the genetic homogeneity of some Salmonella serovars (e.g., ser. Typhimurium) is changeable, but is greater among different species of birds that spend their lives in similar geographical localities. Chrząstek et al. [32] also demonstrated a correlation between genetic homogeneity and the geographical origin of the host, but with Pasteurella multocida strains collected from poultry in different regions in Poland. Our results confirm the genetic similarity of Salmonella ser. Typhimurium strains isolated from wild birds in the area of Wrocław. 


\section{Conclusions}

Salmonella species are present in populations of freeliving bird species, especially in birds sampled in urbanized areas. Some wild avian species are reservoirs for Salmonella serotypes, especially Salmonella ser. Typhimurium Most of the positive samples came from the Eurasian siskin and the greenfinch. The Salmonella isolates presented the same virulence genes as in human clinical isolates. This suggests a potential risk for people feeding infected wild birds.

\section{Availability of supporting data}

The study was conducted with the special consent mentioned in the text above (see Methods). All dead birds (except game birds) were found already dead and brought to the clinic. Game birds were hunted and collected by hunters in accordance with local hunting laws. Samples of great cormorants were obtained during the annual population cull in Poland, in accordance with the annual specifications of the Regional Directorate of Environmental Protection.

\section{Competing interests}

The authors declare that they have no competing interests.

\section{Authors' contributions}

MK (Krawiec): main researcher, collected the samples, performed the microbiological analyses and molecular biological analyses, wrote the paper. MK (Kuczkowski): coordinated the molecular biological analyses. AGK: scientific consultation. AW: principal investigator, scientific coordination of the research and data analysis, collaborated in writing the paper. All authors read and approved the final manuscript.

\section{Acknowledgments}

This research project was financed by the National Centre for Research and Development, project number no. 12012610.

The authors are grateful to Anna Woźniak (PhD) for help with the microbiological analyses, Anna Aksamit (PhD) of the Reference Laboratory for Salmonella (Agro-Vet, Wrocław, Poland) for Salmonella serotyping, and to ornithologist Stanisław Rusiecki, the Odra Wrocław Bird-Ringing Group, the Sudetic Bird-Ringing Group, and the organizers of the Rakutowskie ornithological camp, for their help with collecting the samples.

\section{Author details}

${ }^{1}$ Department of Epizootiology and Clinic of Bird and Exotic Animals, Faculty of Veterinary Medicine, Wrocław University of Environmental and Life Sciences, PI. Grunwaldzki 45, 50-366 Wrocław, Poland. ${ }^{2}$ Warsaw Zoological Garden, ul. Ratuszowa 1/3, 03-461 Warsaw, Poland.

Received: 14 August 2014 Accepted: 22 January 2015

Published online: 31 January 2015

\section{References}

1. Alley MR, Connolly JH, Fenwick SG, Mackereth GF, Leyland MJ, Rogers LE, et al. An epidemic of salmonellosis caused by Salmonella Typhimurium DT 160 in wild birds and humans in New Zealand. N Z Vet J. 2002:50:170-6.

2. Guibourdenche M, Roggentin P, Mikoleit M, Fields PI, Bockemühl J, Grimont PA, et al. Supplement 2003-2007 (no. 47) to the White-Kauffmann-Le Minor scheme. Res Microbiol. 2010;161:26-9.

3. EFSA, ECDC, The European Union summary report on trend and sources of zoonoses, zoonotic agents and footborne outbreaks in 2011. EFSA J. 2013:11:3129-379.

4. Pasmans F, Van Immersel F, Heyndrickx M, Martel A, Godard C, Wildemauwe C, et al. Host adaptation of pigeon isolates of Salmonella enterica subsp. enterica serovar Typhimurium variant Copenhagen phage type 99 is associated with enhanced macrophage cytotoxicity. Infect Immunol 2003:71:6068-74.

5. Lawson B, Howard T, Kirkwood JK, Macgregor SK, Perkins M, Robinson RA, et al. Epidemiology of salmonellosis in garden birds in England and Wales, 1993-2003. Ecohealth. 2012;7:294-306.

6. Tizard IR, Fish RA, Harmeson J. Free flying sparrows as carriers of salmonellosis. Can Vet J. 1979;20:143-4.

7. Hubalek Z, Sixl W, Mikulaskova M. Salmonellosis in gulls and other freeliving birds in Czech Republic. Cent Eur J Public Health. 1995;3:21-4.

8. Winfield MD, Groisman EA. Role of Nonhost environments in the lifestyles of Salmonella and Escherichia coli. Appl Environ Microbiol. 2003;69:3687-94.

9. Skyberg JA, Logue CM, Nolan LK. Virulence genotyping of Salmonella spp. with multiplex PCR. Avian Dis. 2006:50:77-81.

10. Mezal EH, Stefanova R, Khan AA. Isolation and molecular characterization of Salmonella enterica serovar Javiana from food, environmental and clinical samples. Int J Food Microbiol. 2013;164:113-8.

11. Mezal EH, Sabol A, Khan A, Ali N, Stefanova R, Khan AA. Isolation and molecular characterization of Salmonella enterica serovar Enteritidis from poultry house and clinical samples during 2010. Food Microbiol. 2014;38:67-74.

12. Akiyama T, Khan AA, Cheng CM, Stefanova R. Molecular characterization of Salmonella enterica serovar Saintpaul isolated from imported seafood, pepper, environmental and clinical samples. Food Microbiol. 2011;28:1124-8.

13. Lee $K$, Iwata $T$, Shimizu M, Taniguchi T, Nakadai A, Hirota $Y$, et al. A novel multiplex PCR assay for Salmonella subspecies identification. J Appl Microbiol. 2009:107:805-11.

14. Versalovic J, Koeuth T, Lupski JR. Distribution of repetitive DNA sequences in eubacteria and application of fingerprinting of bacterial genomes. Nucleic Acids Res. 1991;19:6823-33.

15. Cizek A, Literak I, Hejlicek K, Treml F, Smola J. Salmonella contamination of the environment and its incidence in wild birds. Zentralbl Veterinarmed $B$. 1994:41:320-7

16. Zaleski S, Jakubowska L. Occurrence of Salmonella in feces of wild birds in Poland. Przegl Epidemiol. 1976;30:511-4.

17. Stenzel T, Tykałowski B, Mazur-Lech B, Koncicki A. Infections in wildlife birds-results of serologcal screening. Bull Vet Inst Pulavy. 2008;52:63-6.

18. Kapperud G, Stenwig H, Lassen J. Epidemiology of Salmonella Typhimurium 0:4-12 Infection in Norway. Evidence of Transmission from an Avian Widlife Reservoir. Am J Epidemiol. 1998;147:774-82.

19. Horton RA, Wu G, Speed K, Kidd S, Davies R, Coldham NG, et al. Wild birds carry similar Salmonella enterica serovar Typhimurium strains to those found in domestic animals and livestock. Res Vet Sci. 2013:95:45-8.

20. Foti M, Rinaldo D, Guerci A, Giacopello C, Aleo A, De Leo F, et al. Pathogenic microorganisms carried by migratory birds passing through the territory of the island of Ustica, Sicily (Italy). Avian Pathol. 2011;40:405-9.

21. Morishita TY, Aye PP, Ley EC, Harr BS. Survey of pathogens and blood parasites in free-living passerines. Avian Dis. 1999;43:549-52

22. Harris JM. Zoonotic diseases of birds. Vet Clin N Am-Small. 1991:21:1289-98.

23. Hughes LA, Shopland S, Wigley P, Bradon H, Leatherbarrow H, Williams $\mathrm{NJ}$, et al. Characterisation of Salmonella enterica serotype Typhimurium isolates from wild birds in northern England from 2005-2006. BMC Vet Res. 2008:4:4.

24. Lawson B, Hughes LA, Peters T, de Pinna E, John SK, Macgregor SK, et al. Pulsed-Field gel electrophoresis supports the presence of host-adapted Salmonella enterica subsp. enterica serovar Typhimurium strains in the British garden bird population. Appl Environ Microbiol. 2011;77:8139-44.

25. Hamer SA, Lehrer E, Magle SB. Wild birds as sentinels for multiple zoonotic pathogens along urban to rural gradient in greater chicago Illinois. Zoonoses Public Health. 2011:59:355-64

26. Borrelli L, Fioretti A, Russo TP, Barco L, Raia P, De Luca Bossa LM, et al. First report of Salmonella enterica serovar Infantis in common swifts (Apus Apus). Avian Pathol. 2013;42:323-6.

27. Refsum T, Heir E, Kapperud G, Vardund T, Holstad G. Molecular epidemiology of Salmonella enterica serovar Typhimurium isolates determined by pulsed-field gel electrophoresis: comparison of isolates from avian wildlife, domestic animals and the environment in Norway. App Environ Microbiol. 2002;68:5600-6.

28. Pennycot TW, Park A, Mather HA. Isolation of different serovars of Salmonella enterica from wild birds in Great Britain between 1995 and 2003. Vet Rec. 2006;158:817-20. 
29. Reche MP, Jimenez PA, Alvarez F. Incidence of Salmonellae in captive and wild free-living raptorial birds in central Spain. J Vet Med B. 2003;50:42-4

30. Hoque MA, Burgess W, Greenhil AR, Hedlefs R, Skerratt LF. Causes of morbidity and mortality of wild aquatic birds at Billabong Sanctuary, Townsville, North Queensland, Australia. Avian Dis. 2012;56:249-56.

31. Daoust PY, Prescott JF. Salmonellosis. In: Thomas NJ, Hunter DB, Atkinson $C T$, editors. Infectious Diseases of Wild Birds. Ames, lowa: Blackwell Publishing Ltd; 2007. p. 270-88.

32. Chrząstek K, Kuczkowski M, Wieliczko AK, Bednarek KJ, Wieliczko A Molecular epidemiologic investigation of Polish avian Pasteurella multocida strains isolated from fowl cholera outbreaks showing restricted geographical and host-specific distribution. Avian Dis. 2012;56:529-36.

\section{Submit your next manuscript to BioMed Central and take full advantage of:}

- Convenient online submission

- Thorough peer review

- No space constraints or color figure charges

- Immediate publication on acceptance

- Inclusion in PubMed, CAS, Scopus and Google Scholar

- Research which is freely available for redistribution 